Jurnal PRISMA Universitas Suryakancana

\title{
PENYUSUNAN BAHAN AJAR KETERAMPILAN DASAR MENGAJAR BERDASARKAN TEORI MULTIPLE INTELLIGENCES DI PERGURUAN TINGGI MUHAMMADIYAH
}

\author{
Eka Novarina ${ }^{1}$, Novi Andri Nurcahyono ${ }^{2}$ \\ ${ }^{1}$ Universitas Muhammadiyah Sukabumi \\ novarinaeka14@yahoo.com \\ ${ }^{2}$ Universitas Muhammadiyah Sukabumi \\ nanurcahyono@ummi.ac.id
}

\begin{abstract}
ABSTRAK
Calon guru perlu dibekali dengan keterampilan dasar mengajar agar dapat mencapai tujuan pembelajaran karena setiap peserta didik memiliki karakter. Salah satu karakter yang perlu diperhatikan adalah jenis kecerdasan yang dimiliki peserta didik. Kecerdasan yang dimiliki peserta didik beragam jenisnya (multiple intelligences) dengan tingkat penguasaan yang berbeda. Untuk itu perlu dikembangkan bahan ajar keterampilan dasar mengajar berdasarkan teori multiple intelligences. Tujuan penelitian ini adalah mendiskripsikan tahapan pengembangan bahan ajar keterampilan dasar mengajar berdasarkan teori multiple intelligences. Penelitian ini merupakan penelitian research and development (R\&D). Rangkaian penelitian dan pengembangan yang dilakukan dimulai dari: (1) studi lapangan meliputi studi pustaka dan deskripsi dan analisis temuan; (2) studi pengembangan meliputi model pengembangan, validasi desain, revisi desain, uji coba produk, revisi produk, evaluasi dan penyempurnaan.
\end{abstract}

Kata Kunci: Bahan Ajar, Keterampilan Dasar Mengajar, Multiple Intelligences.

\section{PENDAHULUAN}

Pemerintah telah melakukan perbaikan terhadap kualitas pendidikan pada beberapa tahun ke belakang. Hal ini dapat dilihat dari meningkatnya anggaran pendidikan menjadi sebesar 20\%, penyusunan kurikulum baru yaitu kurikulum 2013, program pendidikan dan latihan profesi guru (PLPG) yang saat ini menjadi pendidikan profesi guru (PPG), dan tunjangan sertifikasi untuk peningkatan kesejahteraan guru. Dari beberapa perbaikan tersebut, sektor gurulah yang lebih banyak dilakukan oleh pemerintah. Hal ini dikarenakan ujung tombak dalam sebuah pendidikan adalah guru. Dalam pembelajaran, guru harus memperhatikan berbagai macam aspek pendukung. Aspek pendukung tersebut meliputi metode atau model pembelajaran, bahan ajar, sarana dan prasarana pembelajaran, serta tidak 
Jurnal PRISMA Universitas Suryakancana

kalah penting aspek yang berasal dari peserta didik. Aspek yang berasal dari peserta didik salah satunya adalah kecerdasan.

Gardner (2012: 24) mendefinisikan kecerdasan yaitu kemampuan untuk menyelesaikan masalah, atau menciptakan produk, yang berharga dalam satu atau beberapa lingkungan budaya dan masyarakat. Pada dasarnya tidak ada peserta didik yang bodoh, karena setiap peserta didik mempunyai potensi kecerdasan. Seseorang mungkin menonjol pada beberapa jenis kecerdasan, tetapi lemah pada beberapa kecerdasan yang lain. Sebagai contoh, seseorang yang menonjol pada kecerdasan kinestetik mungkin saja lemah pada kecerdasan logismatematis. Dalam diri seseorang terdapat 8 jenis kecerdasan atau sering disebut dengan kecerdasan majemuk (multiple intelligences). Kedelapan jenis kecerdasan tersebut menurut Gardner dalam Hernandez, J., G., V., Noruzi, M., R., dan Sariolghalam, N. (2010) meliputi kecerdasan verbal/linguistik (verbal/ linguistik intelligence), kecerdasan visual/spasial (visual/spatial intelligence), kecerdasan logis-matematis (logical-mathematical intelligence), kecerdasan musik (musical intelligence), kecerdasan tubuh/kinestetik (bodily/kinesthetic intelligence), kecerdasan interpersonal (interpersonal intelligence), dan kecerdasan intrapersonal (intrapersonal intelligence) dan kecerdasan naturalis (naturalist intelligence).

Berdasarkan hasil observasi mahasiswa Magang I Universitas Muhammadiyah Sukabumi pada tahun 2016 di SMP dan SMA di kota Sukabumi, sebagian besar guru hanya menggunakan metode ceramah dan menggunakan papan tulis sebagai media pembelajaran. Praktik pembelajaran seperti ini menjadikan guru kurang memperhatikan keragaman kecerdasan peserta didik. Guru matematika lebih banyak melibatkan kecerdasan logismatematis daripada kecerdasan lain dalam mengajarkan suatu konsep dan keterampilan matematika. Padahal, setiap siswa dapat mempelajari matematika menggunakan variasi kecerdasan yang berbeda-beda walaupun matematika dibangun atas dasar pemikiran yang lebih banyak melibatkan kecerdasan logis-matematis. Armstrong (2009: 65-67) menganjurkan agar pembelajaran didesain dengan cara mempertimbangkan kemungkinan pendekatan kecerdasan yang cocok dengan topik matematika terpilih, memilih dan mengurutkan aktivitas dalam rencana pembelajaran, dan kemudian menerapkannya ke dalam proses pembelajaran. 
Sehingga agar dapat melibatkan kecerdasan majemuk dalam pembelajaran matematika, diperlukan pembelajaran yang sesuai dengan teori multiple intelligences.

Sholikhah, O., H., Budiyono, dan Saputro, D, R., S. (2014) melakukan penelitian dengan hasil penelitiannya yaitu terdapat interaksi antara model pembelajaran dan tipe kecerdasan terhadap prestasi belajar matematika. Selain model pembelajaran, untuk melaksanakan pembelajaran matematika berorientasi multiple intelligences siswa diperlukan keterampilan dasar mengajar dengan indikator berbasis multiple intelligences. Hal ini dikarenakan keterampilan dasar mengajar merupakan syarat mutlak agar guru dapat mengimplementasikan berbagai strategi pembelajaran. Untuk membentuk guru yang memiliki keterampilan dasar mengajar berbasis multiple intelligences, salah satunya dilakukan sejak calon guru tersebut menempuh pendidikan di perguruan tinggi. Melalui mata kuliah microteaching, keterampilan dasar mengajar mahasiswa dibentuk. Dalam proses pengajarannya digunakan bahan ajar sebagai alat bantu.

Berdasarkan data dalam www.muhammadiyah.or.id, Perguruan Tinggi Muhammadiyah (PTM) yang berada di seluruh Indonesia berjumlah 172, dan yang memiliki prodi pendidikan matematika sebanyak 35. Melihat banyaknya program studi matematika di PTM, PTM memiliki potensi yang besar untuk berpartisipasi mencetak calon guru matematika yang memiliki keterampilan dasar mengajar berbasis multiple intelligences. Keterampilan dasar mengajar ini harus memperhatikan multiple intelligences yang ada pada siswa. Menurut Mulyasa, E. (2008) terdapat 8 jenis keterampilan dasar mengajar yaitu, keterampilan membuka pelajaran, keterampilan bertanya, keterampilan memberi penguatan, keterampilan mengadakan variasi, keterampilan menjelaskan, keterampilan membimbing diskusi kelompok, keterampilan mengelola kelas, dan keterampilan menutup pembelajaran. Pada keterampilan dasar mengajar mahasiswa, keterampilan dasar yang dimiliki juga belum memperhatikan multiple intelligencessiswa. Hal ini dapat dilihat dari hasil penelitian Nurcahyono, N. A. dan Novarina, E. (2015) yang menyatakan bahwa mahasiswa hanya menggunakan variasi media berupa media visual dan audio visual. Mahasiswa belum menggunakan media yang memfasilitasi kecerdasan kinestetik. Dalam indikator keterampilan mengadakan variasi, variasi media hanya berkisar media visual dan audio visual. Untuk itu perlu dikembangkan 
Jurnal PRISMA Universitas Suryakancana

indikator keterampilan dasar mengajar berbasis multiple intelligences. Kajian ilmiah tentangindikator keterampilan dasar mengajar berbasis multiple intelligences berguna sebagai dasar bagi diselenggarakannya riset pengembangan bahan ajar keterampilan dasar mengajar berdasarkan teori multiple intelligences bagi calon guru metematika di PTM. Berdasarkan uraian masalah tersebut, maka daftar pertanyaan yang dapat dirumuskan dalam penelitian ini adalah bagimana tahapan pengembangan bahan ajar keterampilan dasar mengajar berdasarkan teori multiple intelligences bagi calon guru metematika di perguruan tinggi Muhammadiyah? Berdasarkan rumusan masalah tersebut, maka tujuan penelitian dalam penelitian ini yaitu: Mendiskripsikan tahapan pengembangan bahan ajar keterampilan dasar mengajar berdasarkan teorimultiple intelligences bagi calon guru metematika di perguruan tinggi Muhammadiyah.

\section{Bahan Ajar Keterampilan Dasar Mengajar Matematika}

Opara, J. A.dan Oguzor, N. S. (2011) mengatakankan bahwa instructional materials are the audio visual materials (software/ hardware) which can be used as alternative channels of communication in the teaching-learning process. Artinya, bahan ajar merupakan sumber belajar berupa visual maupun audiovisual yang dapat digunakan sebagai saluran alternatif pada komunikasi di dalam proses pembelajaran. Berdasarkan definisi tersebut diketahui bahwa bahan ajar memiliki peran penting dalam kegiatan pembelajaran. Hal ini karena bahan ajar merupakan salah satu usaha agar kegiatan pembelajaran dapat terarah dan tujuan pembelajaran tercapai. Sejalan dengan hal tersebut Dick, W., Carey, L. dan Carey, J. O. (2009: 230) mengatakan bahwa instructional material contain the conten either written, mediated, or facilitated by an instructor that a student as use to achieve the objective also include information that the learners will use to guide the progress. Artinya, bahan ajar berisi konten yang perlu dipelajari oleh siswa baik berbentuk cetak atau yang difasilitasi oleh pengajar untuk mencapai tujuan tertentu. Bagi peserta pembelajaran, bahan ajar dapat mengurangi ketergantungan pada pengajar dan dapat melatih kebiasaan belajar mandiri. Bagi pengajar, bahan ajar dapat mengurangi waktu dan tenaga dalam menyajikan materi.

Reber (dalam Syah, M. 2012: 119), menyatakan bahwa keterampilan adalah kemampuan melakukan pola-pola tingkah laku yang kompleks dan tersusun rapi secara mulus 
Jurnal PRISMA Universitas Suryakancana

dan sesuai dengan keadaan untuk mencapai hasil tertentu. Sementara itu, Howard, A. W. dalam Slameto (2010: 32) mengatakan bahwa mengajar adalah suatu aktivitas untuk mencoba menolong, membimbing seseorang untuk mendapatkan, mengubah atau mengembangkan skill, attitude, ideals (cita-cita), appreciations (penghargaan), dan knowledge. Dari pengertian tentang keterampilan dasar dan mengajar, dapat disimpulkan bahwa yang dimaksud dengan keterampilan dasar mengajar dalam penelitian ini adalah aktivitas belajar yang bersifat mendasar dengan menggunakan kumpulan strategi untuk membimbing, menanamkan pengetahuan, mengembangkan skill, attitude, ideals (cita-cita), appreciations (penghargaan) dan knowledge pada anak didik secara cepat dan benar.

\section{Kecerdasan Majemuk (Multiple Intelligences)}

Gardner (Fleetham, M. 2006: 17), mendefinisikan kecerdasan sebagai berikut, "Intelligence is a biopsychological potential to process information that can be activated in a cultural setting to solve problems or create products that are of value in a culture". Artinya, kecerdasan adalah sebuah potensi biopsikologis untuk memproses informasi yang dapat diaktifkan di dalam lingkungan budaya tertentu untuk menyelesaikan permasalahan atau menciptakan produk-produk yang bernilai dalam sebuah budaya. Gardner menemukan dan mengembangkan teori kecerdasan majemuk (multiple intelligences). Dalam menentukan jenis kecerdasan majemuk, Gardner menggunakan delapan kriteria yang sering digunakan untuk menentukan apakah suatu kemampuan manusia sungguh dapat digolongkan sebagai kecerdasan atau tidak. Kriteria-kriteria kemampuan yang dikemukakan Gardner (Armstrong, 2009: 8) itu adalah sebagai sebagai berikut.

Potential isolation by brain damage; (2) The existence of savants, prodigies, and other exceptional individuals; (3) A distinctive developmental history and a definable set of expert "end-state" performances; (4) An evolutionary history and evolutionary plausibility; (5) Support from psychometric findings; (6) Support from experimental psychological tasks; (7) An identifiable core operation or set of operations; (8) Susceptibility to encoding in a symbol system. 
Jurnal PRISMA Universitas Suryakancana

\section{METODE PENELITIAN}

Jenis penelitian ini adalah penelitian $R$ and $D$. Sugiyono (2009) berpendapat bahwa $R$ and $D$ adalah metode penelitian yang digunakan untuk menghasilkan produk tertentu dan menguji keefektifan produk tersebut. Hal ini sejalan dengan pendapat Borg, W. R. dan Gall, M. D. (2003) yang mengatakan mengatakan bahwa prosedur $R$ and $D$ pada dasarnya memiliki dua tujuan utama, yaitu yang pertama mengembangkan produk (fungsi pengembangan) dimana produk yang dihasilkan bisa berupa software, hardware seperti buku, modul alat bantu belajar, sedangkan yang kedua menguji keefektifan produk dalam mencapai tujuan (fungsi validasi). Namun pada penelitian ini hanya akan dibahas prosedur atau tahapan-tahapan dalam menghasilkan produk yaitu bahan ajar. Sugiyono (2009: 314) mengungkapkan bahwa dalam penelitian pengembangan terdapat tiga tahap, yaitu studi pendahuluan, tahap studi pengembangan, dan tahap evaluasi. Pada penelitian ini, langkah-langkah yang digunakan adalah melakukan studi pendahuluan dan studi pengembangan. Studi pengembangan pada penelitian hanya akan dibahas sampai tahap model pengembangan.

\section{HASIL DAN PEMBAHASAN}

Bahan ajar dalam penelitian ini adalah alat dan sumber belajar mahasiswa dalam mata kuliah microteaching yang berisi konten berupa indikator keterampilan dasar mengajar berdasarkan multiple intelligences sebagai alternatif untuk mencapai tujuan pembelajaran. Bahan ajar ini berisi teori dan ilustrasi dari keterampilan dasar mengajar berdasarkan teori multiple intelligences, sehingga bahan ajar ini juga dilengkapi dengan CD. Untuk menyusun bahan ajar tersebut, dilakukan tahap-tahap pengembangan bahan ajar yang dimulai dengan studi pendahuluan. Studi pendahuluan yang dilakukan meliputi studi mengenai standar kompetensi, capaian pembelajaran, dan analisis pembelajaran. Berdasarkan studi pustaka yang dilakukan terhadap Satuan Acara Perkuliahan (SAP) mata kuliah Microteaching diperoleh keterangan sebagai berikut:

a. Standar kompetensi

Setelah mengikuti mata kuliah ini, mahasiswa akan mampu untuk mempraktikan keterampilan dasar mengajar dalam melaksanakan proses pembelajaran. 
Jurnal PRISMA Universitas Suryakancana

b. Capaian pembelajaran

Terdiri dari: 1) Kognitif. Mengaplikasikan konsep-konsep keterampilan dasar mengajar dalam melaksanakan proses pembelajaran; 2) Afektif. Cepat tanggap dalam menghadapi situasi selama proses pembelajaran; 3) Psikomotor. Merancang skema materi dalam kegiatan membuka, inti, dan menutup pelajaran; 4) Tanggung Jawab. Mampu mengambil keputusan yang tepat dan bertindak berdasarkan analisis terhadap informasi serta bertanggung jawab terhadap keputusan dan tindakan tersebut.

c. Analisis pembelajaran

Prasyarat mata kuliah perencanaan pembelajaran di semester VI ini adalah mata landasan pendidikan, kurikulum dan pembelajaran, perkembangan peserta didik, pengelolaan pendidikan, psikologi pendidikan, inovasi pendidikan, strategi pembelajran matematika, media pembelajaran matematika, evaluasi pembelajaran matematika, kapita selekta 1, kapita selekta 2, dan kapita selekta 3. Mata kuliah ini merupakan aplikasi dari materi-materi prasyarat tersebut, yaitu mengidenifikasi, merancang, dan melaksanakan proses pembelajaran.

Pada tahap kedua yaitu pengembangan, hal yang dilakukan meliputi studi tentang komponen-komponen bahan ajar, definisi keterampilan dasar mengajar, jenis-jenis keterampilan dasar mengajar, aspek yang diamati dalam keterampilan dasar mengajar, definisi multiple intelligences, jenis-jenis multiple intelligences, dan aspek yang diamati dalam multiple intelligences. Pada penelitian ini bahan ajar yang dikembangkan berupa modul. Maka desain awal bahan ajar yang dikembangkan mencakup komponen-komponen sebagai berikut: 1) petunjuk penggunaan bahan ajar; 2) content atau materi; 3) informasi pendukung berupa transkip video; 4) evaluasi; dan 5) balikan terhadap hasil evaluasi.

Petunjuk penggunaan bahan ajar diawali dengan uraian mengenai standar kompeteensi, capaian pembelajaran, dan analisis pembelajaran. Petunjuk penggunaan dibagi menjadi 2, yaitu petunjuk untuk pengajar dan petunjuk untuk peserta didik. Selanjutnya, pada bab pertama diisi dengan uraian materi yang terdiri dari teori keterampilan dasar mengajar dan multiple intelligences. Keterampilan dasar mengajar pada bahan ajar yang dikembangkan ini 
didefinisikan sebagai kemampuan yang bersifat mendasar untuk membimbing, menanamkan pengetahuan, mengembangkan skill, attitude, ideals (cita-cita), appreciations (penghargaan), dan knowledge pada anak didik dalam suatu proses belajar. Keterampilan dasar mengajar yang dibahas dalam bahan ajar ini ada 8 jenis, yaitu keterampilan membuka pelajaran, keterampilan bertanya, keterampilan memberi penguatan, keterampilan mengadakan variasi, keterampilan menjelaskan, keterampilan membimbing diskusi kelompok, keterampilan mengelola kelas, dan keterampilan menutup pelajaran.

Aspek yang dilihat pada keterampilan dasar membuka pelajaran adalah: a) Menimbulkan perhatian (gaya mengajar guru, alat bantu mengajar, pola interaksi yang bervariasi); b) Menggunakan pertanyaan-pertanyaan yang mengaitkan antara pengetahuan yang dimiliki siswa sebelumnya dengan materi yang akan dipelajari; c) Memberikan acuan (mengemukakan tujuan pembelajaran, kegiatan yang akan dilakukan, cakupan materi); d) Memotivasi siswa (kehangatan dan antusiasme, menimbulkan keingintahuan, memperhatikan minat siswa).

Aspek yang dilihat pada keterampilan bertanya adalah: a) Pertanyaan yang dikemukakan jelas maksudnya dan benar kaitannya; b) Mengajukan pertanyaan terlebih dahulu kemudian menunjuk salah satu siswa untuk menjawabnya; c) Memberikan waktu yang cukup bagi siswa untuk berpikir dalam menemukan jawabannya; d) Mengajukan pertanyaan kepada siswa secara merata.

Aspek yang dilihat pada keterampilan memberi penguatan adalah: a) Menggunakan penguatan verbal yang berupa kata-kata/kalimat pujian, persetujuan, atau penghargaan; b) Memberi penguatan dengan mimik, gerak badan, mendekati, dan kontak terhadap respon positif siswa; c) Memberi penguatan dengan simbol atau benda yang relevan dan rasional.

Aspek yang dilihat pada keterampilan mengadakan variasi adalah: a) Variasi dalam gaya mengajar guru (suara, mimik dan gerak, kesenyapan, kontak pandang, perubahan posisi, memusatkan pada butir penting); b) Menggunakan variasi penggunaan media pembelajaran (variasi visual, oral, media yang dapat dipegang atau dimanipulasi) yang terkait dengan materi pembelajaran; c) Variasi pola interaksi dan kegiatan siswa (menganeka ragamkan kegiatan belajar siswa). 
Jurnal PRISMA Universitas Suryakancana

Aspek yang dilihat pada keterampilan menjelaskan adalah: a) Menyampaikan materi dengan urutan yang sistematis (terstruktur); b) Menggunakan bahasa lisan dan tulisan secara jelas, baik dan benar serta berbicara lancar (tidak tersendat-sendat); c) Menggunakan kalimat yang tidak berbelit-belit dan menghindari kata yang berlebihan atau meragukan; d) Menggunakan contoh atau ilustrasi; e) Memberi tekanan pada bagian-bagian yang penting; e) Meminta respon atau pertanyaan siswa selama pelajaran berlangsung; f) Menunjukan penguasaan materi; g) Mengaitkan materi dengan materi lain yang relevan; h) Melaksanakan pembelajaran sesuai dengan kompetensi (tujuan yang akan dicapai); i) Mengintegrasikan nilainilai imtaq dalam kegiatan pembelajaran.

Aspek yang dilihat pada keterampilan membimbing diskusi kelompok adalah: a) Memusatkan perhatian anggota kelompok (merumuskan tujuan diskusi, merumuskan masalah, menandai hal-hal yang penting); b) Memperjelas masalah yang akan didiskusikan; c) Membantu kesulitan yang dialami dalam kelompok kecil; d) Meningkatkan partisipasi siswa untuk berpendapat; e) Menyebarkan kesempatan berpartisipasi (mencegah pembicaraan yang berlebihan dan menghindari dominasi); f) Memperjelas penyelesaian soal yang dilakukan dalam kelompok besar; g) Menganalisis pendapat anggota kelompok; h) Membuat simpulan dari hasil diskusi kelompok.

Aspek yang dilihat pada keterampilan mengelola kelas adalah: a) Menciptakan dan memelihara kondisi belajar yang optimal (sikap tanggap, membagi perhatian, menuntut tanggungjawab siswa, memberikan petunjuk yang jelas, menegur siswa); b) Mengembalikan kondisi belajar yang optimal (terhadap gangguan siswa yang berkelanjutan dengan cara memodifikasi tingkah laku); c) Memfasilitasi siswa untuk mencoba, mengamati, menganalisis, dan berkomunikasi; d) Melibatkan siswa dalam pemanfaatan media; e) Melakukan penilaian dalam proses pembelajaran.

Aspek yang dilihat pada keterampilan menutup pelajaran adalah: a) Membimbing siswa dalam membuat rangkuman pelajaran yang mencakup inti materi; b) Memberikan evaluasi secara lisan atau tertulis untuk mengetahui tingkat keberhasilan siswa dan guru dalam melaksanakan kegiatan pembelajaran; c) Memberikan kesempatan bertanya kepada siswa; 
d) Membuat rantai kompetensi antara materi yang diajarkan dengan materi yang akan dipelajari berikutnya.

Setelah mengidentifikasi materi keterampilan dasar mengajar yang akan dikembangkan, maka materi selanjutnya yaitu multiple intelligences. Gardner mengungkapkan bahwa kemampuan-kemampuan manusia yang dapat digolongkan sebagai kecerdasan dapat dikategorikan ke dalam sembilan jenis kecerdasan. Kecerdasan-kecerdasan itu adalah kecerdasan verbal/ linguistik (verbal/ linguistic intelligence), kecerdasan visual/ spasial (visual/ spatial intelligence), kecerdasan logis-matematis (logical-mathematical intelligence), kecerdasan musik (musical intelligence), kecerdasan tubuh/ kinestetik (bodily/ kinesthetic intelligence), kecerdasan interpersonal (interpersonal intelligence), kecerdasan intrapersonal (intrapersonal intelligence), kecerdasan naturalis (naturalist intelligence), dan kecerdasan eksistensial (existential intelligence). Masing-masing kecerdasan tersebut diintegrasikan pada kegiatan pembuka, inti, dan penutup dalam pembelajaran. Integrasi tersebut berupa ilustrasi pembelajaran dari masing-masing komponen keterampilan dasar mengajar yang disimpan di dalam CD. Ilustrasi di dalam video tersebut dilengkapi dengan transkip yang dituliskan di bahan ajar. Selain itu, terdapat penjelasan dari masing-masing ilustrasi.

Bahan ajar ini juga dilengkapin dengan evaluasi berupa soal pada masing-masing bab. Untuk evaluasi terakhir, mahasiswa diminta untuk menganalisis sebuah ilustrasi pembelajaran sesuai keterampilan dasar mengajar berdasarkan teori multiple intelligences. Evaluasi yang disediakan dilengkapi dengan kunci jawaban dan pembehasan sebagai balikan terhadap evaluasi.

Selain komponen-komponen bahan ajar, pengembangan bahan ajar ini juga memperhatikan unsur ketertarikan/minat baca terhadap bahan ajar. Unsur ketertarikan tersebut berupa desain cover, komposisi warna di dalam bahan ajar, layout, keterbacaan, dan kebahasaan. Cover di desain menarik dengan penambahan ilustrasi dan komposisi pewarnaan. Lembar di setiap halaman di dalam bahan ajar berwarna. Layout atau tata letak ini meliputi tata letak tulisan dan tata letak gambar. Keterbacaan di sini adalah ukuran huruf dan jenis huruf yang digunakan di dalam bahan ajar. Kebahasaan dilakukan dengan memastikan bahwa uraian materi di bahan ajar menggunakan bahasa yang baku dan ejaan yang sesuai EYD. 
Jurnal PRISMA Universitas Suryakancana

Namun, pada transkip pembelajaran, bahasa yang digunakan sesuai dengan bahasa lisan yang terekam di dalam video sehingga tidak ada proses editing untuk kebahasaan.

\section{KESIMPULAN}

Langkah-langkah dalam pengembangan bahan ajar yang dilakukan adalah: (1) studi pendahuluan, (2) studi pengembangan. Studi pendahuluan dilakukan dengan mengkaji pustaka terkait komponen-komponen bahan ajar, keterampilan dasar mengajar, dan teori multiple intelligences. Studi pengembangan dilakukan dengan menyusun bahan ajar sesuai komponenkomponen yang diperlukan yaitu Petunjuk penggunaan bahan ajar, content atau materi, informasi pendukung berupa transkip video, evaluasi, dan balikan terhadap hasil evaluasi.

\section{REFERENSI}

Armstrong, T. (2009). Multiple Inteligences in The Classroom ( $3^{\text {rd }}$ ed.). Virginia USA: ASCD Alexandria.

Borg, W. R. dan Gall, M. D. (2003). Educational Research: an information (7th ed). New York: Longman Inc.

Dick, W., Carey, L. dan Carey, J. O. (2009). The Systematic Design Of Instruction (7th Edition). Upper Saddle River, NJ: Pearson.

Fleetham, M. (2006). Multiple Intelligences in Practice: Enhancing Self-Estem and Learning in the Classroom. Cornwall: Network Continuum.

Gardner, H. (2012). Multiple Intelligences: Kecerdasan Majemuk Teori dalam Praktik. Tangerang Selatan: Intraksara.

Hernandez, J., G., V., Noruzi, M., R., dan Sariolghalam, N. (2010). Multiple Intelligences as a New Paradigm in the Education of Mexico.International journal of Education. 2, (1), $1-18$.

Mulyasa, E. (2008). Menjadi Guru Profesional. Bandung: PT Remaja Rosdakarya.

Nurcahyono, N. A. dan Novarina, E. (2015). Analisis Keterampilan Dasar Mengajar Mahasiswa Dalam Pelaksanaan Program Latihan Profesi (PLP). Utile Jurnal Kependidikan.1,(2), 162-172.

Opara, J. A. dan Oguzor, N. S. (2011). Instructional Technologies and School Curriculum in Nigeria: Innovations and Challenges. Perspectives of Innovations, Economics \& Business. 7, (1), 66-71.

Sholikhah, O., H., Budiyono, dan Saputro, D, R., S. (2014). Eksperimentasi Model Pembelajaran Kooperatif Tipe Group Investigation (GI) dan Number Heads Together (NHT) Pada Materi Gris Singgung Lingkaran Ditinjau Dari Kecerdasan Majemuk Siswa Kelas VIII SMP Negeri Sekota Madiun Tahun Ajaran 2013/2014. Jurnal Elektronik Pembelajaran Matematika. 2, (7), 727-739. 
Jurnal PRISMA Universitas Suryakancana

Slameto. (2010). Belajar dan Faktor-Faktor yang Mempengaruhinya. Jakarta: Rineka Cipta. Syah, M. (2012). Psikologi Belajar. Jakarta: Raja Grafindo Persada.

Sugiyono. (2009). Metode Penelitian Kuantitatif, Kualitatif, dan R\&D. Bandung: Alfabeta. 